\title{
Interactive comment on "A regional hindcast model simulating ecosystem dynamics, inorganic carbon chemistry and ocean acidification in the Gulf of Alaska" by Claudine Hauri et al.
}

\section{Anonymous Referee \#2}

Received and published: 14 April 2020

The comment was uploaded in the form of a supplement:

https://www.biogeosciences-discuss.net/bg-2020-70/bg-2020-70-RC2-supplement.pdf

Interactive comment on Biogeosciences Discuss., https://doi.org/10.5194/bg-2020-70, 2020. 